\title{
Epidemiological investigation of the role of family susceptibility and occupational and family histories in the development of byssinosis among workers exposed to flax dust*
}

\author{
MADBULI H. NOWEIR, EZZAT K. AMINE, and HASSAN A. OSMAN \\ High Institute of Public Health, University of Alexandria, Egypt
}

\begin{abstract}
Noweir, Madbuli H., Amine, Ezzat K., and Osman, Hassan A. (1975). British Journal of Industrial Medicine, 32, 297-301. Epidemiological investigation of the role of family susceptibility and occupational and family histories in the development of byssinosis among workers exposed to flax dust. Epidemiological investigation of 475 workers exposed to dust in flax processing has shown that family susceptibility has a decisive role in the development of byssinosis in those workers. Workers whose fathers had occupational history of exposure to flax dust were more resistant to the development of the disease than those whose fathers had no such history. Such tolerance was much higher in workers whose fathers were byssinotic than those with byssinosis-free fathers. Further hereditary and immunological investigations are, however, needed.
\end{abstract}

Byssinosis has been known to occur among workers exposed to cotton, flax, and some other vegetable dusts (Schilling et al., 1964). There is evidence, however, from the surveys of exposed workers that individual susceptibility is an important factor in the development of the disease. Some workers are more 'reactive' to the exposure than other fellow workers. Smoking, exposure to general atmospheric pollution, and previous history of allergic asthma and other specific or non-specific respiratory diseases have been suggested as contributory factors. However, there is, at present, no proven test to differentiate those who are specially likely to develop byssinosis.

In the present study, the part played by heredity and occupational and past medical family histories

*This work was supported by the USPHS PL-480 Project 03-001-3 in the development of byssinosis has been investigated in an endeavour to elucidate some of the parameters which determine the extent of individual susceptibility in the development of the disease.

\section{Methods}

The population in this study included: (1) all workers involved in manual flax processing in 14 workshops $(n=406)$ randomly selected out of the 56 shops located in the town of Menuf, where the Egyptian manual flax processing industry has been concentrated for historical, economic, and ecological reasons (Noweir et al., 1975a); and (2) all workers employed in the two plants that process flax semi-mechanically in the same town $(n=69)$.

The industrial operations and environmental exposure in both the manual processing and in the semi-mechanical processing have been described in preceding articles (Noweir et al., 1975a, b).

Each worker was privately interviewed for his social, personal, familial, occupational, and past medical 
history; as well as for the occupational history of his father, grandfather, sons, and other relatives who were involved in flax processing. Particular attention was paid to respiratory and allergic diseases and smoking habits. A questionnaire on chest symptoms, based on the experience developed in the studies of byssinosis in Egypt and the questionnaire used by Roach and Schilling (1960), was completed. This was followed by a thorough medical examination. The questionnaire and the medical examination were conducted privately for each subject and without knowledge of the results of examination of his relatives or fellow workers. Workers of the same family were then grouped together and interviewed again to double-check the degree of consanguinity between the different members of the family and their occupational history.

Byssinosis was diagnosed and graded as recommended by the Sub-committee on Respiratory Diseases in Textile Workers of the Permanent Commission and International Association on Occupational Health (Schilling et al., 1964).

\section{Results}

The prevalence of byssinosis in some of the families is presented in Table 1. Families that have three or more workers involved in flax processing are inclu ded in the Table. The mean age and duration of exposure of the workers' family groups are also presented for comparison. The members of some families (from nos 1 to 7) were completely free from byssinosis, while those in some other families (nos 24 and 25) were all byssinotic. Byssinosis prevailed in the other families to different extents. The mean age and duration of exposure of many families are nearly similar, while the prevalence of byssinosis among the family members was drastically different, for example, families nos $1,3,4,6$ versus families 16 , $17,18,19,20,23$. Examples of the data of some selected families (nos 4, 13, 15, 23, 24) are presented in Table 2. Data presented in both Tables show that members of some families were highly susceptible to byssinosis, while others were resistant. Again, duration of exposure appeared to be of secondary importance in the development of disease among the workers examined. For example, two subjects in family 15 (Table 2) were exposed to dust for 34 and 50 years without developing byssinosis, while another one in the same family developed byssinosis after three years' exposure.

In order to test for the significance of the family factor, and for the lack of significance of duration of exposure, on the development of byssinosis in families, the brothers involved in the study $(n=144)$ were grouped into pairs (older and younger) and classified according to the diagnosis of byssinosis (that is, byssinotic or byssinosis-free); the results are presented in Table 3 . In some families, there

\section{TABLE 1}

Prevalence of Byssinosis in Different Families Involved in Flax Processing

\begin{tabular}{|c|c|c|c|c|c|}
\hline \multirow{2}{*}{ Family no. } & \multirow{2}{*}{$\begin{array}{l}\text { No. of subjects } \\
\text { exposed to flax dust }\end{array}$} & \multirow{2}{*}{$\begin{array}{l}\text { Age (years) } \\
\text { mean } \pm S D\end{array}$} & \multirow{2}{*}{$\begin{array}{c}\text { Duration of exposure } \\
\text { mean } \pm S D\end{array}$} & \multicolumn{2}{|c|}{ Byssinotic subjects } \\
\hline & & & & No. & $\%$ \\
\hline $\begin{array}{r}1 \\
2 \\
3 \\
4 \\
5 \\
6 \\
7 \\
8 \\
9 \\
10 \\
11 \\
12 \\
13 \\
14 \\
15 \\
16 \\
17 \\
18 \\
19 \\
20 \\
21 \\
22 \\
23 \\
24 \\
25\end{array}$ & $\begin{array}{r}6 \\
6 \\
8 \\
13 \\
5 \\
4 \\
4 \\
8 \\
6 \\
6 \\
8 \\
8 \\
7 \\
19 \\
8 \\
4 \\
4 \\
4 \\
8 \\
4 \\
4 \\
3 \\
4 \\
4 \\
3\end{array}$ & $\begin{array}{l}35.5 \pm 16.2 \\
29.8 \pm 8.3 \\
34.6 \pm 20.1 \\
33.6 \pm 14.2 \\
23.8 \pm 7.4 \\
32.8 \pm 13.3 \\
35.0 \pm 6.7 \\
31.1 \pm 16.8 \\
51.3 \pm 10.0 \\
29.2 \pm 17.8 \\
35.4 \pm 18.2 \\
34.6 \pm 17.3 \\
27.6 \pm 12.4 \\
29.3 \pm 14.1 \\
40.8 \pm 16.0 \\
33.3 \pm 7.3 \\
33.8 \pm 15.5 \\
33.3 \pm 25.8 \\
35.4 \pm 19.0 \\
33.3 \pm 25.8 \\
22.3 \pm 11.3 \\
45.0 \pm 17.4 \\
32.8 \pm 13.3 \\
31.3 \pm 8.5 \\
18.7 \pm 2.5\end{array}$ & $\begin{array}{l}20.7 \pm 13.2 \\
13.0 \pm 6.0 \\
24.9 \pm 15.5 \\
20.9 \pm 11.2 \\
13.4 \pm 6.3 \\
22.0 \pm 14.0 \\
18.8 \pm 7.2 \\
16.3 \pm 9.6 \\
34.2 \pm 13.6 \\
15.7 \pm 12.0 \\
22.1 \pm 16.0 \\
22.1 \pm 16.6 \\
16.4 \pm 11.6 \\
14.0 \pm 10.6 \\
27.1 \pm 15.1 \\
21.8 \pm 5.3 \\
23.0 \pm 13.2 \\
20.8 \pm 19.3 \\
23.4 \pm 16.2 \\
20.8 \pm 19.3 \\
12.0 \pm 10.4 \\
31.7 \pm 14.6 \\
22.0 \pm 14.0 \\
17.8 \pm 7.0 \\
10.3 \pm 3.8\end{array}$ & $\begin{array}{l}0 \\
0 \\
0 \\
0 \\
0 \\
0 \\
0 \\
1 \\
1 \\
1 \\
2 \\
2 \\
2 \\
6 \\
4 \\
2 \\
2 \\
2 \\
4 \\
2 \\
2 \\
2 \\
3 \\
4 \\
3\end{array}$ & $\begin{array}{c}0 \\
0 \\
0 \\
0 \\
0 \\
0 \\
0 \\
12 \cdot 5 \\
16 \cdot 7 \\
16 \cdot 7 \\
25 \cdot 0 \\
25 \cdot 0 \\
28 \cdot 6 \\
31 \cdot 6 \\
50 \cdot 0 \\
50 \cdot 0 \\
50 \cdot 0 \\
50 \cdot 0 \\
50 \cdot 0 \\
50 \cdot 0 \\
50 \cdot 0 \\
66 \cdot 6 \\
75 \cdot 0 \\
100 \cdot 0 \\
100 \cdot 0\end{array}$ \\
\hline
\end{tabular}


TABLE 2

Byssinosis Subjects in Some Families

\begin{tabular}{|c|c|c|c|c|c|}
\hline Family & Subject & Position in family & Age & $\begin{array}{c}\text { Duration of } \\
\text { exposure }\end{array}$ & Byssinotics \\
\hline \multirow{3}{*}{ IV } & $\begin{array}{l}1 \\
2 \\
3 \\
4\end{array}$ & $\begin{array}{l}\text { Father } \\
\text { Son } \\
\text { Son } \\
\text { Uncle }\end{array}$ & $\begin{array}{l}63 \\
33 \\
42 \\
43\end{array}$ & $\begin{array}{l}40 \\
21 \\
35 \\
33\end{array}$ & $\begin{array}{l}- \\
- \\
-\end{array}$ \\
\hline & $\begin{array}{l}5 \\
6 \\
7\end{array}$ & $\begin{array}{l}\text { Father } \\
\text { Son } \\
\text { Son }\end{array}$ & $\begin{array}{r}37 \\
8 \\
12\end{array}$ & $\begin{array}{r}20 \\
3 \\
4\end{array}$ & $\begin{array}{l}- \\
-\end{array}$ \\
\hline & $\begin{array}{r}8 \\
9 \\
10 \\
11 \\
12 \\
13\end{array}$ & $\begin{array}{l}\text { Cousin } \\
\text { Cousin } \\
\text { Cousin } \\
\text { Cousin } \\
\text { Cousin } \\
\text { Cousin }\end{array}$ & $\begin{array}{l}20 \\
35 \\
35 \\
40 \\
32 \\
37\end{array}$ & $\begin{array}{l}10 \\
20 \\
20 \\
25 \\
15 \\
25\end{array}$ & $\begin{array}{l}- \\
- \\
- \\
- \\
-\end{array}$ \\
\hline \multirow[t]{3}{*}{ XIII } & $\begin{array}{l}1 \\
2 \\
3 \\
4\end{array}$ & $\begin{array}{l}\text { Father } \\
\text { Son } \\
\text { Uncle } \\
\text { Uncle }\end{array}$ & $\begin{array}{l}50 \\
21 \\
40 \\
21\end{array}$ & $\begin{array}{l}37 \\
13 \\
28 \\
11\end{array}$ & $\begin{array}{l}+ \\
+ \\
-\end{array}$ \\
\hline & $\begin{array}{l}5 \\
6 \\
7\end{array}$ & $\begin{array}{l}\text { Cousin } \\
\text { Cousin } \\
\text { Cousin }\end{array}$ & $\begin{array}{l}17 \\
21 \\
23\end{array}$ & $\begin{array}{r}4 \\
11 \\
11\end{array}$ & $\begin{array}{l}- \\
-\end{array}$ \\
\hline & $\begin{array}{l}1 \\
2 \\
3\end{array}$ & $\begin{array}{l}\text { Father } \\
\text { Son } \\
\text { Son }\end{array}$ & $\begin{array}{l}50 \\
22 \\
13\end{array}$ & $\begin{array}{r}34 \\
10 \\
3\end{array}$ & $\overline{-}$ \\
\hline \multirow[t]{2}{*}{ XV } & $\begin{array}{l}4 \\
5 \\
6\end{array}$ & $\begin{array}{l}\text { Uncle } \\
\text { Uncle } \\
\text { Uncle }\end{array}$ & $\begin{array}{l}19 \\
66 \\
21\end{array}$ & $\begin{array}{l}14 \\
50 \\
11\end{array}$ & $\overline{-}$ \\
\hline & $\begin{array}{l}7 \\
8\end{array}$ & $\begin{array}{l}\text { Cousin } \\
\text { Cousin }\end{array}$ & $\begin{array}{l}45 \\
47\end{array}$ & $\begin{array}{l}30 \\
35\end{array}$ & $\begin{array}{l}+ \\
+\end{array}$ \\
\hline XXIII & $\begin{array}{l}1 \\
2 \\
3 \\
4\end{array}$ & $\begin{array}{l}\text { Cousin } \\
\text { Cousin } \\
\text { Cousin } \\
\text { Cousin }\end{array}$ & $\begin{array}{l}27 \\
20 \\
51 \\
33\end{array}$ & $\begin{array}{l}16 \\
10 \\
42 \\
20\end{array}$ & $\begin{array}{l}+ \\
\dot{+} \\
+\end{array}$ \\
\hline XXIV & $\begin{array}{l}1 \\
2 \\
3 \\
4\end{array}$ & $\begin{array}{l}\text { Brother } \\
\text { Brother } \\
\text { Cousin } \\
\text { Cousin }\end{array}$ & $\begin{array}{l}30 \\
20 \\
35 \\
40\end{array}$ & $\begin{array}{l}14 \\
10 \\
25 \\
22\end{array}$ & $\begin{array}{l}+ \\
+ \\
+ \\
+\end{array}$ \\
\hline
\end{tabular}

TABLE 3

Prevalence of Byssinosis Among Examined Brothers' Pairs

\begin{tabular}{|c|c|c|c|c|c|c|c|}
\hline & & & & & \multicolumn{3}{|c|}{ Older brothers } \\
\hline & & & & & Byssinotics & Free & Total \\
\hline \multirow[t]{2}{*}{ Younger brothers } & $\begin{array}{l}\text { Byssinotics } \\
\text { Free . . }\end{array}$ & $\begin{array}{l}\cdots \\
\cdots\end{array}$ & $\begin{array}{l}\cdots \\
\cdots\end{array}$ & $\begin{array}{l}\cdots \\
\cdots\end{array}$ & $\begin{array}{l}9 \\
9\end{array}$ & $\begin{array}{l}13 \\
49\end{array}$ & $\begin{array}{l}22 \\
58\end{array}$ \\
\hline & Total .. & . & . & . & 18 & 62 & 80 \\
\hline
\end{tabular}

$\chi^{2}$ not significant 
TABLE 4

Age ANd Duration of Exposure of Examined Brothers

\begin{tabular}{|c|c|c|c|c|c|}
\hline & & $\begin{array}{l}\text { Older brothers } \\
\quad n=80\end{array}$ & $\begin{array}{l}\text { Younger brothers } \\
\quad n=80\end{array}$ & $t$ & $P$ \\
\hline $\begin{array}{l}\text { Age (years) mean } \pm \text { SD } \\
\text { Duration of exposure (years) mean } \ddot{ \pm} \text { SD } \ldots\end{array}$ & $\begin{array}{l}\cdots \\
\cdots\end{array}$ & $\begin{array}{l}42 \cdot 7 \pm 3 \cdot 1 \\
28 \cdot 1 \pm 2 \cdot 4\end{array}$ & $\begin{array}{l}28 \cdot 6 \pm 2 \cdot 6 \\
15 \cdot 4 \pm 2 \cdot 0\end{array}$ & $\begin{array}{l}31 \cdot 26 \\
36 \cdot 99\end{array}$ & $\begin{array}{l}<0.01 \\
<0.01\end{array}$ \\
\hline
\end{tabular}

were three brothers involved: the middle one was counted once as the younger relative to the oldest brother and once as the older relative to the youngest one. This increased the number of brothers' pairs to 80. Comparisons of the corresponding mean age and duration of exposure of the older and younger brothers are also presented in Table 4. In spite of the fact that the older brothers were exposed to flax dust for significantly longer durations $(P<0.01)$ than the younger brothers (Table 4), the prevalence of byssinosis in both groups was not statistically different (Table 3).

Table 5 presents the prevalence of byssinosis among examined workers in relation to the history of their fathers' exposure to dust. The Table also includes comparison of other factors that may be contributing to the prevalence of byssinosis, namely, age and smoking habits. The prevalence of byssinosis was significantly higher $(P<0.05)$ among those with fathers with no history of exposure to flax dust than in the other group. This difference appeared after exposure to dust for longer than 10 years. However, the prevalence of byssinosis was lower among those exposed for 30 years in the first group than in the second group. Meanwhile, no significant difference was observed in the mean age and the number of smokers among the examined workers in the two groups.

Data collected from the fathers examined in the present study $(n=35)$ and their sons are presented
TABLE 6

Byssinosis Among Examined Sons Versus Byssinosis Among EXamined Fathers

\begin{tabular}{cll|c|c|c}
\hline & & \multicolumn{3}{|c}{ Fathers } \\
\cline { 3 - 5 } & & Byssinotic & Free & Total \\
\hline \multirow{3}{*}{ Sons } & Byssinotic &.. & 0 & 13 & 13 \\
& Free &. & 2 & 24 & 26 \\
& Total &.. & 2 & 37 & 39 \\
& & & & \\
\hline
\end{tabular}

in Table 6. Four of the fathers had two sons examined and, therefore, were included in the Table twice, which increased the number of fathers in the Table to 39. None of the sons whose fathers were byssinotic developed the disease, while all the byssinotic sons $(n=13)$ had byssinosis-free fathers. Analysis of the data by the marginal $\chi^{2}$ test showed that the prevalence of byssinosis among descendants of byssinotic fathers was significantly lower $(P<$ 0.01 ) than among descendants of byssinosis-free fathers.

\section{Discussion}

This investigation shows that some factors inherited in families play a part in the development of byssinosis. The members of some families were

TABLE 5

Prevalence of Byssinosis Among Examined Workers Versus Exposure History of Fathers to Flax Dust

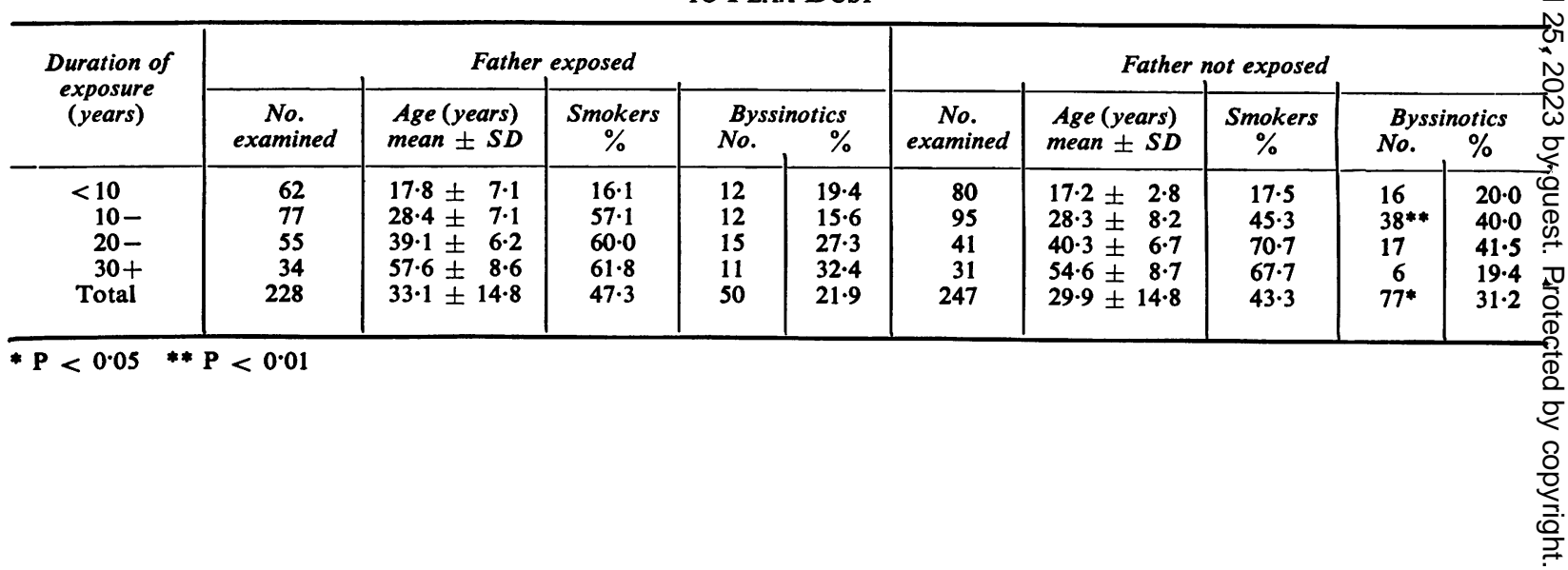


highly susceptible to flax dust and developed byssinosis, while the members of other families were resistant to such exposure. Susceptibility, however, varies to a great extent among different families. Within each family, this factor was so decisive in the development of the disease that it overshadowed the duration of exposure to flax dust. Little is known about family susceptibility to disease (Hill and Hill, 1955). However, there is evidence that family susceptibility may have a role in the incidence of some respiratory diseases, for example, tuberculosis. Factors determining such susceptibility in the incidence of byssinosis should be subjected to further intensive investigations.

Another factor that has been demonstrated in the present study to contribute to resistance to byssinosis is the father's history of exposure to flax dust and/or his history of development of byssinosis. Workers whose fathers had a history of exposure to flax dust were more resistant to the development of the disease than those with fathers without such a history (Table 5). It may be interesting to stress that most of the fathers, if not all of them, had a history of considerable exposure before their marriage. For example, the average age at the beginning of exposure among the different members of the examined families ranged from 8.2 to $17 \cdot 1$ years (Table 1). The apparently lower prevalence of byssinosis among workers exposed for 30 years and with fathers with no history of dust exposure than in those whose fathers had such history, may be due to the fact that a few of the workers who develop byssinosis leave their work, particularly at older ages. The rate of turnover among this segment of old workers is higher among those whose fathers were not exposed to flax than in the other group. Workers in the latter group have traditional family links with their occupation.

Within such a group of workers whose fathers had a history of dust exposure, it has also been shown that those whose fathers had had byssinosis were more resistant to the development of the disease than workers whose fathers were free from the disease. It may thus be concluded that the fathers' exposure to flax dust increases the tolerance of their sons to the development of byssinosis when the sons themselves are exposed to such dust. Also byssinosis in the father increases such tolerance in their sons. Whether such tolerance is immunological or due to a desensitization mechanism is unknown and needs further investigation.

The data in this paper, while presenting valuable observations about the importance of such factors as family susceptibility and family occupational and medical histories in the development of byssinosis, present an invitation to scientists in the field of heredity and immunology to investigate further the actual role of such factors in the aetiology of the disease.

\section{References}

Hill, J. B. and Hill, H. D. (1955). Genetics and Human Heredity, p. 490. McGraw-Hill, London.

Noweir, M. H., El-Sadek, Y., El-Dakhakhny, A. A., and Osman, H. A. (1975a). Dust exposure in manual flax processing in Egypt. British Journal of Industrial Medicine, 32, 147-154.

, El-Dakhakhni, A. A., Osman, H. A., and Moselhi, M. (1975b). Seasonal exposure to dust in flax processing in Egypt. American Industrial Hygiene Association Journal, 36, 318-324

Roach, S. A. and Schilling, R. S. F. (1960). A clinical and environmental study of byssinosis in the Lancashire cotton industry. British Journal of Industrial Medicine, 17, 1-9.

Schilling, R. S. F., Vigliani, E. C., Lammers, B., Valić, F., and Gilson, J. C. (1964). A report on a conference on byssinosis. Proceedings of the XIVth International Congress of Occupational Health, Madrid, 1963, vol. 2, pp. 137-145. Excerpta Medica Foundation, Amsterdam.

Received for publication 18 February 1975. Accepted for publication 13 June 1975. 